\title{
Kecakapan Lulusan Program Studi Teologi yang Menjawab Kebutuhan Gereja
}

\author{
Gidion \\ Sekolah Tinggi Teologi Kristus Alfa Omega \\ gideonjosila@gmail.com
}

\begin{abstract}
There are indications of dissatisfaction of graduate users of Kristus Alfa Omega Theological College's graduates' skill. Regarding this issue, the research focuses on: First, how big is the need of Pentecostal-Charismatic Churches on the provided qualification by Theology department in Kristus Alfa Omega Theological College? Second, how big is the need of the Pentecostal-Charismatic Churches in ministry-support media skill? Third, what is the holistic skill of Kristus Alfa Omega Theological College graduates needed most by the Pentecostal-Charismatic Churches? This research uses a quantitative research method with a descriptive study. The result was that $99.2 \%$ of the skill needed by Pentecostal-Charismatic Churches had been provided by the Theology Department of Kristus Alfa Omega Theological College. The five most graduate skill's needed are Bible interpreting skills, preaching, evangelizing, leadership, new ministry planting, character, spirituality, and multimedia. It is hoped that this research will become a consideration for any Theological Colleges in formulating its curriculum.
\end{abstract}

Keywords: Graduate proficiency; Theology Departement; Pentacostal-Charismatic Church

\begin{abstract}
Abstrak
Ada indikasi pengguna lulusan kurang puas dengan kecakapan lulusan di STT Kristus Alfa Omega. Berdasarkan permasalahan ini, maka penelitian ini berfokus meneliti: Pertama, seberapa besar tingkat kebutuhan Gereja aliran Pentakosta Kharismatik pada kecakapan yang telah diberikan oleh Prodi Teologi STT KAO? Kedua, seberapa besar tingkat kebutuhan Gereja aliran Pentakosta Kharismatik pada kecakapan menggunakan media untuk menunjang pelayanan masa kini. Ketiga, apa saja kecakapan holistik dari lulusan Prodi Teologi STT KAO yang paling dibutuhkan oleh Gereja aliran Pentakosta Kharismatik? Penelitian ini menggunakan metode kuantitatif, dengan jenis riset studi deskriptif. Hasilnya bahwa nilai tingkat kebutuhan Gereja aliran Pentakosta Kharismatik pada kecakapan yang telah diberikan oleh Prodi Teologi STT KAO adalah 99,2\%. Lima kecakapan yang paling dibutuhkan dari seorang lulusan adalah adalah kecakapan tafsir kitab, kecakapan kotbah, kecakapan penginjilan, kecakapan kepemimpinan, kecakapan mendirikan pos pelayanan, kecakapan karakter, kecakapan rohani, dan kecakapan multimedia. Harapannya hasil penelitian ini menjadi materi pertimbangan bagi Perguruan Tinggi Teologi dalam merumuskan kurikulum.
\end{abstract}

Kata Kunci: Kecakapan Lulusan; Prodi Teologi; Aliran Pentakosta Kharismatik

\section{PENDAHULUAN}

Seorang lulusan yang memiliki kemampuan atau kecakapan juga

mempunyai kriteria-kriteria tertentu dalam 
penjelasan pasal 35 Undang-Undang

Nomor 20 tahun 2003 dikatakan bahwa standar kompetensi lulusan merupakan kualifikasi kemampuan kelulusan yang mencakup sikap, pengetahuan, dan keterampilan peserta didik yang harus dipenuhinya atau juga dicapainya dari suatu satuan pendidikan. ${ }^{1}$ Kecakapan adalah kemampuan dan pengetahuan seseorang untuk berani menghadapi problema hidup dan kehidupan secara proaktif mencari serta menemukan solusi sehingga akhirnya mampu mengatasinya dengan kemampuan berinteraksi dan beradaptasi dengan orang lain, keterampilan mengambil keputusan, pemecahan masalah, berfikir kritis, berfikir kreatif, berkomunikasi yang efektif, membina hubungan antar pribadi, kesadaran diri, berempati, mengatasi emosi dan mengatasi stres. ${ }^{2}$ Yorke dan Knight menjelaskan bahwa setiap lulusan yang ingin masuk dunia kerja perlu memiliki kecakapan kerja yang baik, yang diantaranya adalah keterampilan kerja, pemahaman, dan atribut personal yang mendukung lulusan diterima di dunia kerja dan menjadi sukses. ${ }^{3}$ Jadi setiap lulusan

1 "Undang-Undang No 20 Pasal 35

Tentang Sistem Pendidikan Nasional," http://pendis.kemenag.go.id/file/dokumen/uun o20th2003ttgsisdiknas.pdf.

${ }^{2}$ Murniati Agustian, Keterampilan Dasar Dalam Proses Pembelajaran (Jakarta: Unika Atma Jaya, n.d.).

${ }^{3}$ Mantz Yorke and Peter T. Knight, "Curricula for Economic and Social Gain,"
Pendidikan teologi perlu memiliki kecakapan, yang menjadikannnya mampu berkontribusi baik di dunia kerja.

Kunandar mengatakan bahwa kecakapan lulusan di Indonesia masih jauh dari apa yang diharapkan, hal itu terbukti dari banyaknya lulusan pendidikan tinggi yang belum siap untuk masuk dalam dunia kerja. $^{4}$ Dunia kerja (gereja/lembaga rohani) berharap banyak dengan skill yang dimiliki para lulusan dari perguruan tinggi Teologi, namun lulusan itu tampaknya adalah orang-orang yang belum siap masuk dalam dunia kerja.

W.C Weld dalam penelitiannya kepada para pimpinan gereja mengenai kelemahan sekolah tinggi teologi, menemukan bahwa Sekolah Teologi tidak mampu menghasilkan lulusan yang dibutuhkan oleh gereja. Lebih lanjut Weld menjelaskan bahwa sekalipun lulusan telah diperlengkapi secara akademis, namun semua itu tidak memampukannya dalam memberikan sumbangsih kehidupan kerohanian dan pengetahuan teologi dari umat yang dilayaninya. ${ }^{5}$ Kebutuhan dunia pelayanan yang berorientasi kepada

Higher Education (2006): 565-568.

${ }^{4}$ Kunandar, Guru Profesional Implementasi Kurikulum Satuan Pendidikan (KTSP) Dan Sukses Dalam Sertifikasi Guru, Penerbit PT. Raja Grafindo Persada: Jakarta (Jakarta: PT RajaGrafindo Persada, 2010), 1.

${ }^{5}$ W.C. Weld, The World Directory of Theological Education by Extension (South Pasadena: William Carrey Library, 1973), 1820. 
pengembangan kehidupan rohani dan pengetahuan rohani kurang dapat dipenuhi oleh kecakapan lulusan perguruan tinggi Teologi.

Burke mengemukakan bahwa "competence is a construct, and not something that we can observe directly". ${ }^{6}$ Kompetensi seseorang terdiri dari dua kemampuan, yaitu teknis (hard skills) dan non-teknis (soft skills). Kedua kompetensi ini berhubungan dengan kecakapan seorang lulusan. Kecakapan bisa diartikan sebagai kemampuan, perlengkapan, elemen atau hasil keluaran pembelajaran, dan keahlian. Jadi berdasarkan pembahasan tentang kecakapan lulusan program studi di atas, dapatlah disimpulkan maknanya yaitu; kemampuan kerja lulusan yang mencakup pengetahuan, keterampilan, dan sikap dalam menghadapi tugas pelayanan di dunia kerja.

Gereja sebagai lembaga rohani juga membutuhkan Pelayan Tuhan dengan karakter dan nilai-nilai hidup yang mencerminkan kebenaran Firman Allah. Lulusan perlu memiliki pengetahuan moral, perasaan moral, dan tindakan moral yang baik.

Thomas mengatakan bahwa pengetahuan moral berbicara tentang kecakapan memahami cara pandang

${ }^{6}$ A.Burke A, Competence Supporting in College To Find Best Career Choice (NZ: Education Center Publishing, n.d.), 40. orang lain, mengetahui aturan nilai moral yang berlaku di tempat tersebut). Perasaan moral berbicara tentang siap hati nurai seorang Lulusan kepada orang disekitarnya, mampun mengendalikan diri dengan baik. Tindakan moral berbicara tentang kemampuan atau keinginan seorang lulusan melakukan tindakantindakan moral. ${ }^{7}$

Gereja membutuhkan lulusan yang memiliki tiga hal di atas, yang penting dalam menunjang aktifitas pelayanan. Bukan hal baru jika sampai saat ini masih ada Gereja pengguna lulusan yang mengeluhkan permasalahan moral dari lulusan Sekolah Teologi. Pabrik lulusan yang dalam hal ini adalah Sekolah Teologi perlu membenahi semua hal yang terkait dalam pengembangan moral mahasiswa.

Permasalahan belum baiknya kecakapan lulusan dalam menjawab kebutuhan pelayanan dalam gereja, disebabkan adanya permasalahanpermasalahan yang terus hadir dalam dunia Pendidikan teologi. Young menjelaskan bahwa ada tiga hal yang secara terus menerus menjadi masalah dalam pendidikan sekolah teologi, hal ini diduga menjadi penyebab kurang baiknya kualitas lulusan di mata pengguna lulusan. Pertama, mata kuliah yang diajarkan lepas dari kehidupan nyata, sehingga kurang

\footnotetext{
7 Thomas Lickona, Educating For
} Character (Jakarta: Bumi Aksara, n.d.), 84. 
bermanfaat. Kedua, tidak tersedianya mata kuliah yang mempelajari budaya kehidupan di perkotaan dan di pedesaan, sehingga pelayanan para lulusan menjadi kurang relevan. Ketiga, kelompok mata kuliah (biblika, dogmatika, sejarah gereja, praktika, dll) tidak tampak jelas terikat dalam satu tujuan yang jelas, yaitu misi gereja. $^{8}$

Permasalahan kurangnya kecakapan lulusan tidak hanya disebabkan oleh masalah pemilihan mata kuliah saja, tetapi juga pada kegiatan penelitian dan pengabdian masyarakat yang berlaku di Sekolah Teologi. Sekolah Teologi mengenal ketentuan pemerintah mengenai dharma perguruan tinggi yang sering disebut tridharma perguruan tinggi. Tridharma perguruan tinggi adalah dharma Pendidikan, penelitian, dan pengabdian kepada masyarakat yang harus dilaksanakan oleh setiap perguruan tinggi. Dosen dan mahasiswa perlu membiasakan diri untuk melakukan kegiatan penelitian dan pengabdian kepada masyarakat. Melalui kegiatan penelitian, dosen dan mahasiswa mengetahui apa permasalahanpermasalahan masa kini dalam pelayanan gereja yang memerlukan jawaban melalui suatu penelitian. Melalui kegiatan pengabdian, dosen dan mahasiswa

${ }^{8}$ M Young, "Theological Approaches to Some Perpetual Problems in Theological Education," Christian Education Journal 2, no. 1 (n.d.): $75-87$. mengetahui seberapa baik kontribusi keilmuan yang telah dimiliki dalam menjawab kebutuhan atau permasalahan di jemaat. Hal yang sering terjadi, ada banyak hasil penelitian yang mendalam tentang pengetahuan Alkitab itu gagal disajikan menjadi materi-materi yang siap pakai untuk dengan mudah dapat dikonsumsi oleh jemaat.

Berdasarkan data penelitian sebelumnya tentang seberapa baik kecakapan lulusan S1 Teologi, ditemukan bahwa kecakapan kepemimpinan, kecakapan pelayanan, dan kecakapan pengetahuan teologi dari lulusan STT KAO belum memenuhi kebutuhan Gereja. ${ }^{9}$ Sekolah Teologi ini telah terakreditasi baik prodi dan institusi dengan jumlah dosen yang lebih dari $50 \%$ bergelar Doktor. Sarana pembelajaran telah tersedia dengan baik, namun semua ini tidak secara otomatis menghasilkan kualitas lulusan yang dapat menjawab kebutuhan gereja. Lebarnya kerapatan jaring seleksi penerimaan dan kelulusan Mahasiswa, diduga sebagai penyebab terjadinya permasalahan ini.

Komunikasi antara penyelenggara pendidikan dengan pengguna lulusan tidak

\footnotetext{
${ }^{9}$ Gidion Gidion, "Kecakapan Lulusan Pendidikan Tinggi Teologi Menghadapi Kebutuhan Pelayanan Gereja Dan Dunia Pendidikan Kristen," KURIOS (Jurnal Teologi dan Pendidikan Agama Kristen) 6, no. 1 (2020): 73-86, http://www.sttpb.ac.id/ejournal/index.php/kurios/article/view/144.
} 
dilakukan secara intens. Gereja seakanakan tidak dapat menentukan isi kurikulum di Sekolah Teologi, dan Sekolah Teologi yang yakin dengan kurikulumnya tanpa terlebih dahulu mendengarkan kebutuhan Gereja sebagai pengguna lulusan. Masalah-masalah ini diduga menjadi penyebab belum tuntasnya pekerjaan rumah Sekolah Teologi dalam meluluskan lulusan dengan kecakapan yang dapat menjawab kebutuhan Gereja.

Kecakapan lulusan program studi Teologi, tampak dari kurikulum yang disajikan program studi. Kurikulum pendidikan berperan penting dalam menghasilkan lulusan yang dapat menjawab kebutuhan pelayanan gerejawi. Kurikulum mempunyai posisi sentral dalam mewujudukan perangkat rencana dan pengaturan mengenai tujuan, isi dan bahan pembelajaran untuk mencapai tujuan pendidikan tertentu. ${ }^{10}$ Tanpa adanya kurikulum, maka kebutuhan pelayanan gerejawi tidak dapat terpenuhi dengan baik. Kurikulum disebut juga sebagai $a$ plan of learning atau sebuah rencana pembelajaran. Kesulitan dalam mencapai tujuan dan saran pendidikan yang dicitacitakan dapat muncul apabila tidak adanya

\footnotetext{
${ }^{10}$ Jahya Yudrik dkk, Pandangan Pelaksanaan Kurikulum (Jakarta: Departemen Agama R.I, n.d.), 4.
}

kurikulum yang baik. ${ }^{11}$

Menurut Nurgiantoro kurikulum mempunyai fungsi tiga hal. Pertama, sebagai pedoman untuk mengatur kegiatan-kegiatan pendidikan yang dilaksanakan. Kedua, mengontrol proses Pendidikan, sehingga tidak terjadi pengulangan kegiatan pengajaran sebelumnya. Ketiga, menyiapkan lulusan menjawab kebutuhan masyarakat atau lapangan kerja, sehingga kurikulum mencerminkan hal-hal yang menjadi kebutuhan masyarakat. ${ }^{12}$

Skill yang dipersiapkan kepada mahasiswa selama berada di bangku kuliah, nyatanya tidak sesuai dengan apa yang dibutuhkan dalam dunia kerja (Gereja). Pernyataan ini disebutkan oleh Kellerman dan Sagmeister yang menjelaskan bahwa sulitnya lulusan memasuki dunia kerja disebabkan oleh perbedaan besar antara skill yang dipersiapkan Perguruan Tinggi dengan skill yang dibutuhkan dunia kerja. ${ }^{13}$ Kecakapan yang diberikan oleh perguruan

${ }^{11}$ Abdullah, Pengembangan Kurikulum Teori Dan Praktek (Jakarta: Gaya Media Pratama, n.d.), 3.

${ }^{12}$ Nurgiyantoro Burhan, Dasar-Dasar Pengembangan Kurikulum Sekolah; Sebuah Pengantar Teoritis Dan Pelaksanaan (Yogyakarta: BPFE, n.d.), 45-46.

${ }^{13}$ Kellermann P and G Sagmeister, "Higher Education and Graduate Employment in Austria," European Journal of education 35, no. 2 (2000): 8. 
tinggi kepada mahasiswa tampak dari kurikulum yang disajikan. Peninjauan kurikulum adalah hal mutlak yang konsisten harus dilakukan oleh pimpinan perguruan tinggi. Peninjauan kurikulum perlu didasarkan pada pencarian data kebutuhan dunia pelayanan gereja.

Banyaknya mata kuliah tentang pengetahuan Alkitab daripada mata kuliah praktika atau terapan dianggap sebagai penyebab permasalahan kecakapan lulusan. Sweeney dan Fortunis tahun 1993 melakukan riset mengenai kompetensi lulusan Sekolah Teologi yang sangat diharapkan oleh jemaat. Berdasarkan riset tersebut ditemukan bahwa kecakapan yang paling dibutuhkan jemaat adalah keterampilan berkhotbah, dan keterampilan yang paling kurang dibutuhkan adalah pengetahuan Alkitab yang mendalam. ${ }^{14}$ Sekolah Teologi dituntut menghasilkan lulusan yang tidak hanya cakap dalam pengetahuan yang mendalam tentang Alkitab, namun juga cakap dalam pelayanan praktis di Gereja. Namun demikian Sweeney dan Furtosis juga mengatakan dalam bukunya, "sekalipun ada banyak mata kuliah yang tidak relevan dan bermanfaat secara langsung kepada gereja, namun pembelajaran Alkitab yang mendalam di

${ }^{14}$ J. Sweeney and S. Fortosis, "Seminary and Church: Allies For Change," Christian Education Jurnal 14, no. 3 (1994): 75.
Sekolah Teologi adalah hal esensial yang menjadi penjaga pengajaran yang Alkitabiah dalam gereja secara lebih luas". ${ }^{15}$ Jadi Sekolah Teologi dengan segala keterbatasannya dituntut oleh gereja untuk menyiapkan pelayan yang berkualitas baik dalam pengetahuan Alkitab dan juga keterampilan pelayanan.

Ada Gereja yang menuntut lebih pada kecakapan lulusan Sekolah Teologi, namun lulusan tersebut tidak sanggup memenuhi tuntutan Gereja tersebut, dan pada akhirnya lulusan itupun mengakhiri pelayanannya di Gereja tersebut. Hal ini terjadi karena keterbatasan konsep, model, dan proses penyelenggaraan pendidikan yang dimiliki Sekolah Teologi. ${ }^{16}$ Akibatnya dihasilkan lulusan yang tidak dapat menjawab kebutuhan Gereja.

Pada penelitian ini ditetapkan varibel kecakapan holistik lulusan program studi teologi Sekolah Tinggi Teologi Kristus Alfa Omega yang dibutuhkan gereja aliran Pentakosta Kharismatik, sebagai fokus penelitian. Penelitian ini bertujuan untuk memotret kebutuhan gereja aliran Pentakosta Kharismatik sebagai pengguna lulusan program studi teologi di STT KAO. Penelitian ini penting untuk segera dilakukan, untuk memberikan informasi yang teruji, dan juga menjadi data evaluasi pengembangan kecakapan mahasisiwa di

\footnotetext{
${ }^{15}$ Ibid.

${ }^{16}$ Ibid.
} 
STT KAO.

\section{METODE PENELITIAN}

Rancangan penelitian yang digunakan adalah kuantitatif bukan eksperimental, yaitu dengan melakukan penelitian studi deskriptif. Sumber data penelitian ini adalah para pemimpin Gereja sebagai pengguna lulusanan program studi Teologi sebanyak 30 orang. Rumusan masalah dalam penelitian ini adalah; Pertama, seberapa besar tingkat kebutuhan Gereja aliran Pentakosta Kharismatik pada kecakapan yang telah diberikan oleh Prodi Teologi STT KAO? Kedua, kecakapan lulusan manakah yang dinilai paling penting dalam menjawab kebutuhan Gereja aliran Pentakosta Kharismatik? Ketiga, apa saja kecakapan holistik dari lulusan Prodi Teologi STT KAO yang paling dibutuhkan oleh Gereja aliran Pentakosta Kharismatik?

Adapun instrument tertutup yang digunakan ada 11 item; 1) Mahasiswa menguasai cara menafsir/menganalisa Alkitab dengan benar. 2) Mahasiswa mampu berkotbah dengan baik. 3) Mahasiswa mampu melakukan pelayanan pelepasan. 4) Mahasiswa antusias melakukan pelayanan visitasi. 5) Mahasiswa cakap melakukan penginjilan kepada yang belum percaya. 6) Mahasiswa cakap melakukan pelayanan konseling kepada jemaat. 7) Mahasiswa memiliki kecakapan dalam memimpin dan mengembangkan pelayanan. 8) Mahasiswa terampil dalam menggunakan multimedia untuk menunjang pelayanan masa kini. 9) Mahasiswa mampu dalam membuka pos pelayanan baru. 10) Mahasiswa memiliki cara berkomunikasi yang sopan. 11) Mahasiswa telah mengalami kepenuhan Roh Kudus, dan suka berdoa. Ada 2 item instrument terbuka, yaitu; 1) Mohon menyebutkan secara urut, paling sedikit 5 hal yang harus dimiliki oleh lulusan Sekolah Teologi? 2) Apakah ada keterampilan 5 lainnya yang kurang dimiliki oleh Mahasiswa Sekolah Teologi?

\section{HASIL DAN PEMBAHASAN}

Berdasarkan data yang telah dikumpulkan dari angket penelitian, maka didapatkan hasil perhitungan range, mean, median, modus, dan standar deviasi adalah pada tabel berikut:

\section{Statistics}

Total Variabel X
\begin{tabular}{|l|r|}
\hline $\mathrm{N} \quad$ Valid & 30 \\
\multicolumn{1}{|c|}{ Missing } & 0 \\
Mean & 54.60 \\
Median & 55.00 \\
Mode & 55 \\
Std. Deviation & .724 \\
Range & 2 \\
Minimum & 53 \\
Maximum & 55 \\
Sum & 1638 \\
\hline
\end{tabular}

Tabel Deskripsi Data Kecakapan Holistik 
Lulusan Program Studi Teologi Sekolah Tinggi Teologi Kristus Alfa Omega yang Dibutuhkan Gereja Aliran Pentakosta Kharismatik se-Kota Semarang

Berdasarkan penghitungan uji normalitas data variabel kecakapan holistik lulusan program studi teologi Sekolah Tinggi Teologi Kristus Alfa Omega yang dibutuhkan gereja aliran Pentakosta Kharismatik, didapatkan nilai absolute adalah 0,443 dan nilai Kolmogrof Smirnov $Z$ adalah 2,427. Hasil uji normalitas dengan metode Kolmogrov Smirnov dengan aplikasi SPSS versi 17 dapat dilihat pada Tabel.

\begin{tabular}{|c|c|c|}
\hline \multicolumn{3}{|c|}{ One-Sample Kolmogorov-Smirnov Test } \\
\hline & & $\begin{array}{l}\text { Total } \\
\text { Variabē } \mathrm{X}\end{array}$ \\
\hline $\mathrm{N}$ & & 30 \\
\hline \multirow{2}{*}{ Normal Parameters ${ }^{a, b}$} & Mean & 54.60 \\
\hline & Std. Deviation & .724 \\
\hline \multirow[t]{3}{*}{ Most Extreme Differences } & Absolute & .443 \\
\hline & Positive & .290 \\
\hline & Negative & -.443 \\
\hline Kolmogorov-Smirnov Z & & 2.427 \\
\hline Asymp. Sig. (2-tailed) & & .000 \\
\hline
\end{tabular}

Tabel Kecakapan Holistik Lulusan Program Studi Teologi Sekolah Tinggi

Teologi Kristus Alfa Omega yang Dibutuhkan Gereja Aliran Pentakosta Kharismatik

Oleh karena nilai absolute lebih besar dari nilai taraf signifikansi $(0,05)$, atau $0,443>0,05$ maka data variabel dinyatakan berdistribusi normal. Selain itu, nilai Kolmogrof Smirnov $Z$ terbukti lebih besar dari nilai nilai taraf signifikansi $(0,05)$, atau $2,427>0.05$ maka data variabel ini dinyatakan berdistribusi normal.

Berikut grafik normal P-P Plot

variabel kecakapan holistik lulusan

program studi teologi Sekolah Tinggi

Teologi Kristus Alfa Omega yang

dibutuhkan gereja aliran Pentakosta

Kharismatik:

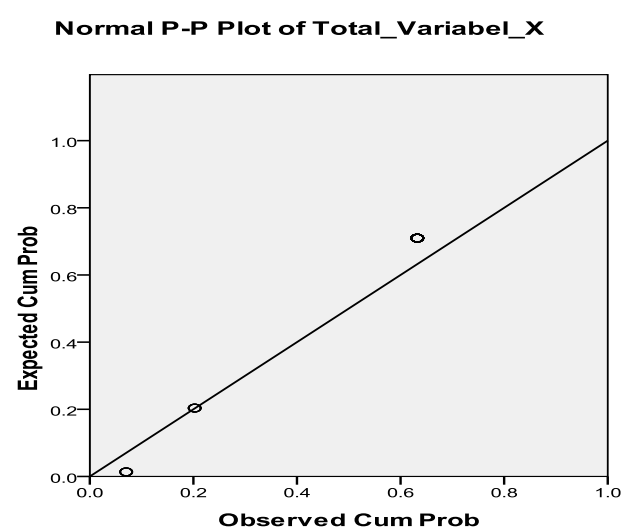

Gambar 4.15 Grafik Normal P-P Plot

Berdasarkan grafik normal P-P Plot diatas diperoleh penyebaran data (titiktitik) mendekati pada garis lurus maka data dinyatakan berdistribusi normal.

Berdasarkan analisis data yang telah dilakukan, diperoleh hasil sebagai berikut: Pertama, nilai kesesuaian antara kecakapan holistik lulusan yang diberikan program studi teologi Sekolah Tinggi Teologi Kristus Alfa Omega dengan kecakapan lulusan yang dibutuhkan gereja aliran Pentakosta Kharismatik adalah $99,2 \%$ atau sangat tinggi.

Kedua, kecakapan holistik lulusan 
program studi teologi Sekolah Tinggi Teologi Kristus Alfa Omega yang paling dibutuhkan oleh gereja aliran Pentakosta Kharismatik adalah keterampilan menggunakan media untuk menunjang pelayanan masa kini, dinyatakan diterima. Berdasarkan analisa ini, diketahui juga bahwa kecakapan lulusan yang dinilai sangat penting atau yang memiliki nilai $100 \%$ (sama dengan nilai kecakapan multimedia) adalah kecakapan tafsir kitab, kecakapan kotbah, kecakapan penginjilan, kecakapan kepemimpinan, kecakapan mendirikan pos pelayanan, kecakapan karakter, dan kecakapan rohani.

Ketiga, berikut diurutkan dari yang tertinggi sampai yang terendah, lima (5) kecakapan yang paling dibutuhkan pemimpin gereja dari lulusan program studi Teologi STT KAO yaitu;

i). Kecakapan Rohani

ii). Kecakapan Karakter

iii). Kecakapan Kotbah

iv). Kecakapan Komunikasi

v). Kecakapan Menafsir Alkitab

Berikut diurutkan dari yang tertinggi sampai yang terendah, lima (5) kecakapan yang kurang dimiliki lulusan program studi Teologi STT KAO yaitu;

i). Kecakapan Entrepreuner

ii). Kecakapan Pertanian dan Perkebunan

iii). Kecakapan bermain Musik iv). Memiliki Sikap Inisiatif

v). Kecakapan Servis Elektronik

\section{KESIMPULAN DAN SARAN}

Kecakapan holistik lulusan program studi teologi yang paling dibutuhkan oleh gereja aliran Pentakosta Kharismatik adalah kecakapan rohani, kecakapan karakter, kecakapan kotbah, kecakapan komunikasi, kecakapan tafsir kitab, kecakapan multimedia, kecakapan penginjilan, kecakapan kepemimpinan, dan kecakapan mendirikan pos pelayanan baru. Kecakapan tambahan dari setiap lulusan program studi Teologi, yang juga menjadi kebutuhan pengguna lulusan adalah kecakapan entrepreuner, kecakapan pertanian dan perkebunan, kecakapan bermain musik, memiliki sikap inisiatif, dan kecakapan servis elektronik. STT Kristus Alfa Omega dan juga Perguruan Tinggi Teologi lainnya perlu memperhatikan apa yang menjadi kebutuhan dari pengguna lulusan ini, sehingga dapat menghasilkan lulusan yang berguna atau menjawab kebutuhan pelayanan Gereja masa kini.

\section{DAFTAR PUSTAKA}

A, A.Burke. Competence Supporting in College To Find Best Career Choice. NZ: Education Center Publishing, n.d. 
Abdullah. Pengembangan Kurikulum

Teori Dan Praktek. Jakarta: Gaya

Media Pratama, n.d.

Agustian, Murniati. Keterampilan Dasar

Dalam Proses Pembelajaran. Jakarta:

Unika Atma Jaya, n.d.

Burhan, Nurgiyantoro. Dasar-Dasar

Pengembangan Kurikulum Sekolah;

Sebuah Pengantar Teoritis Dan

Pelaksanaan. Yogyakarta: BPFE, n.d.

dkk, Jahya Yudrik. Pandangan

Pelaksanaan Kurikulum. Jakarta:

Departemen Agama R.I, n.d.

GIDION, Gidion. Kecakapan Lulusan

Pendidikan Tinggi Teologi

Menghadapi Kebutuhan Pelayanan

Gereja dan Dunia Pendidikan

Kristen. KURIOS (Jurnal Teologi dan

Pendidikan Agama Kristen), 2020,

6.1: 73-86..

J. Sweeney and S. Fortosis. "Seminary and

Church: Allies For Change."

Christian Education Jurnal 14, no. 3

(1994): 75.

Kellermann P and G Sagmeister. "Higher

Education and Graduate Employment

in Austria." European Journal of

education 35, no. 2 (2000): 8.

Kunandar. Guru Profesional Implementasi

Kurikulum Satuan Pendidikan

(KTSP) Dan Sukses Dalam Sertifikasi

Guru. Penerbit PT. Raja Grafindo

Persada: Jakarta. Jakarta: PT

RajaGrafindo Persada, 2010.
Lickona, Thomas. Educating For

Character. Jakarta: Bumi Aksara, n.d.

W.C. Weld. The World Directory of

Theological Education by Extension.

South Pasadena: William Carrey

Library, 1973.

Yorke, Mantz, and Peter T. Knight.

"Curricula for Economic and Social

Gain." Higher Education (2006):

$565-568$.

Young, M. "Theological Approaches to

Some Perpetual Problems in

Theological Education." Christian

Education Journal 2, no. 1 (n.d.).

"Undang-Undang No 20 Pasal 35 Tentang

Sistem Pendidikan Nasional.”

http://pendis.kemenag.go.id/file/doku

men/uuno20th2003ttgsisdiknas.pdf. 